\title{
Subjective Poverty of Youth in Rural Areas of Serbia
}

\author{
Sreten M. Jelić \\ University of Belgrade, Faculty of Agriculture, Serbia \\ e-mail: sjelic@agrif.bg.ac.rs
}

\author{
Vukašin Kolarević* \\ University of Belgrade, Faculty of Agriculture, Serbia \\ e-mail:vukasinkolarevic@gmail.com
}

\begin{abstract}
Poverty is a complex phenomenon faced by youth too. The purpose of this research is to determine the presence of the problem of poverty among youth in rural areas of Serbia. Survey has been conducted in five villages of Paraćin municipality. Exactly 98 young men and women took part in the survey, ages between 20 and 34, and they were asked to answer questions regarding poverty, to estimate their own poverty, and their own social exclusion. Desk research was supplemented with empirical research in the mentioned areas. Results of research conducted in the field are represented in the second part of this paper. In order to perceive the position and poverty of youth, their satisfaction with their living environment, and social exclusion of youth, we relied on the questionnaire that enables expressing subjective welfare. Data obtained through research indicate that one in ten subjects of the survey is poor. The surveyed subjects belonging to the oldest age group (30-34 years of age) and residents of settlements in the vicinity of municipality's center are in a more unfavorable position. Survey results show that the young in rural areas have been facing the problem of their own poverty to a great extend during their lives. Social exclusion was recorded with $42 \%$ of the subjects, who claimed that they had felt isolated from the community at some point in the past two years, due to lack of money.
\end{abstract}

Key words: subjective poverty, youth, rural areas, social exclusion.

*Master's degree student of Agricultural and rural development 


\section{Introduction}

Poverty is a widely spread phenomenon in rural areas of Europe. This problem particularly affects the lives of youth, and their level of satisfaction with their own life. Poverty, often seen as lack of financial means needed to satisfy basic life needs, demands broader monitoring through dimensions of material deprivation and social exclusion.

Problem of poverty and social exclusion was also recognized by the EU, and its reduction is one of the goals of the Europe 2020 strategy. Given the fact that youth represents a "pillar" of society and mostly determines the prospect of its development (Nikolić, 2004:7), it is important to track paths and difficulties that the youth faces. "The young are a very vulnerable and imperiled segment of population, due to various reasons, with large-scale social changes always affecting them the hardest" (Mojić, 2012:5). The young represent a significant part of population in rural areas of Serbia. For this reason, and many other reasons such are specific dispersion of educational institutions, characteristic methods of finding employment and properties of rural environment, the position of youth ought to hold a more significant place in research of rural population situation.

Subjective poverty is defined based on the attitude of the surveyed subjects on the level of income which represents the limit of poverty and/or classification of the surveyed subjects in groups depending on the level of poverty. By examining poverty using the concept of subjective poverty, we can complement the evaluation of data regarding poverty, collected using official statistical research, and gain insight into new details about the problem of poverty for a target category and observed geographical location. Perceptions of the young from rural areas, regarding their financial position and the influence of lack of funds on their position within the community they live in can greatly supplement the gap caused by the insufficiently researched position of youth in rural areas of Serbia.

This research aims to show data on poverty of youth in rural areas of Serbia collected in previous researches and to provide an assessment of subjective poverty of this category of population based on data collected using empirical research. Ditto, this paper also examined the understanding of the problem of poverty by youth in rural areas.

\section{Research Methods}

Lack of official definition of rural areas in Serbia notably hinders the process of drawing adequate conclusions in relation to the processes and problems occurring in the said areas. For the purpose of this research, settlements observed as rural are those settlements which were defined as other, according to a legal criterion used in the Census of Population, Households and Dwellings in the Republic of Serbia for the year 2011 (Vukmirovic, 2012b). Therefore, it was precisely these settlements, listed under other, that were selected for surveying youth. Urban settlement, even though it lacked the city status, was excluded from the analysis. Urban settlement, 
at the same time the center of municipality, was observed exclusively as a criterion for the selection of other settlements, in accordance with their geographical position in relation to the central settlement.

Because of the analysis of data from the database Socijalni profil opština (Social Profile of Municipalities), which includes no dichotomy between urban and other settlements, a classification of municipalities into more urban and more rural was performed. The key criterion of this classification was the city status held by the municipality's center. Municipalities containing settlements that have city status, determined by the Law on Territorial Organization ${ }^{1}$, were observed as more urban municipalities. Names of cities are listed in the part of the paper titled Data on poverty of youth in rural areas of Serbia. Municipalities whose seats do not possess city status were observed as rural municipalities.

Taking into account the phenomenon of prolonged transitions of the young, from schooling till employment, but also the general extended period of functional and financial emancipation from their parents, it is clear that the age interval for this age category is expanded. These processes are also characteristic for rural areas. Tomanović (2012a:12) considers that for the purpose of research which focus on youth and their problems, the upper age limit should be set at 30 or even 35 .

Data presented in this paper were gathered through two phases of research. The first phase included a review analysis of data regarding poverty of youth in rural areas. The second part, qualitative research, was conducted through semi-structured interviews with the young from rural areas. The survey sample included 98 young people from five villages in Paraćin municipality. The head office of this municipality, the urban settlement of Paraćin, does not hold the city status, which was the criterion used in the selection of research territory. According to data gathered in the last census of population in the Republic of Serbia, 518.688 young people, ages between 20 and 34, lived in settlements under the category of other (Vukmirović, 2012b:43). For a population of this size, the size of the sample was set by determining the level of reliability of $95 \%$, and the interval of reliability of 10 . The necessary size of the sample, 96 surveyed, was exceeded in order to prevent problems which may occur in the process of data entry, i.e. lack of some answers.

The young were classified based on the distance of their place of dwelling from the municipality's center, and based on their age into three age groups. Research was conducted in five villages of Paraćin municipality. For the sake of determining the significance of geographical location for the position of youth, these settlements were divided into those in the vicinity of the municipality's center (Striža and Tekija), and those which are significantly distant (Raševica, Potočac i Svojnovo).The lastmentioned settlements are more than seven kilometers away from the municipality's center, while Striža and Tekija are adjacent to it. For the purpose of this paper, significantly distant settlements were designated in this way, because young people living in these settlements need to use their own automobileor services of public transportation

${ }^{1}$ Law on Territorial Organization (Official Gazetteof RS, No. 29/2007 and 18/2016) 
in order to reach municipality's center. Consequently, for this group of youth, the municipality center, as the "nucleus" of employment offer formation and other activities, is less available. A similar division was made in the Pavis et al. (2000:2) and Cartmel \& Furlong (2000:31-33) research, due to the influence of geographical position of youth within rural areas, into categories signifying their economic stability, possibility of finding adequate employment and their status within their community. The sample was also divided into three age groups, namely: 20-24, 25-29 and 30-34 years of age. This was done for the purpose of gaining insight into the period of transition of youth, which represents a particularly fertile ground for the problem of poverty.

Namely, the youth in Serbia is characterized by a slower tempo of transition into adulthood, with a recorded high level of their financial dependence (ages between 19 and 24) on their parents (Tomanović, 2012b:82-84), which can affect the rating of subjective poverty.

Set of questions which was used to establish the opinions of youth about the problem of poverty consists of open and closed questions. The open questions were questions which allowed the young to describe the notion of poverty and to highlight the actors which could help the youth in their struggle with poverty. Answers were coded, and then classified into an appropriate group of answers. Subjective poverty of youth was recorded using two variables in this research. The youth used the first variable to assess whether the income at the disposal of their household was enough to place it outside of poverty. The second variable indicates the percentage of youth which experienced the feeling of poverty in their lifetime, to a certain extent. Financial position of the youth affects their social position, which was also a subject of this research.

This set of questions provided us with the answer whether or not the young in rural areas were poor. If they answered that they were poor, the answer allowed us to establish the percentage of representation intervals of the mentioned category in overall youth population in rural areas.

A SPSS software package, version 21, performed the descriptive analysis of the gathered data.

\section{Defining Objective and Subjective Poverty}

\subsection{Objective Poverty}

Determination of the rate of objective line of poverty depends on the approach used to calculate it. Objective poverty is determined based on absolute or relative line of poverty. Albeit the approach of absolute poverty is abandoned in EU countries, it still represents an important indicator of life quality of the Balkan states residents. This approach enables us to determine the percentage of population unable to satisfy their basic living needs measured using a consumer basket. In EU countries, this concept is perceived as a concept of extreme poverty, something that cannot be 
said for official statistics of Serbia. Extreme poverty is largely equated with absolute poverty across the EU, since a certain group of people, such are the homeless, is exposed to it (Matković, 2014:11). However, the concept of extreme poverty in Serbian statistics is interpreted through the perspective of food, i.e. the quantity of consumption necessary for satisfaction of basic needs for food (RZS, 2008:182). While absolute poverty is based on measuring consumption, relative poverty is based on the assessment of situation on the basis of income. Relative poverty is measured using multiple indicators, with the rate of risk of poverty being the most emphasized in publication of results. This indicator shows the percentage of population whose equivalent income is under the line representing $60 \%$ of the median of equivalent national income (RZS, 2015:4). Moreover, this percentage does not represent the percentage of the poor, but the percentage of those individuals which are at a higher risk of entering poverty.

The general problem of an objective approach to measuring poverty consists of finding an appropriate and reliable economic resource, which is at people's disposal, and defining how and where to draw the line of poverty (Penttilä \& Nordberg, 1999:1).

\subsection{Subjective Poverty}

Measuring absolute and relative poverty is supplemented with the concept of subjective poverty. Subjective poverty data can be used to test objective lines of poverty, but also to identify social problems and to create an evaluation of objective policies (Matković, 2014:19-20). Having in mind that the high natural consumption and low representation of income coming from a full- time employment are characteristic for rural areas, concept of subjective poverty can be used to surpass these limitations, which can occur during the process of measuring objective poverty. Namely, the percentage of natural consumption in other areas of Serbia is 10,6\%, while income coming from a full-time employment represent about $37 \%$ of total income in money and income in kind (Republički zavod za statistiku, 2017:7).

Subjective poverty represents a measure established using a personal attitude of the surveyed regarding his position and possibility to find himself outside of poverty. As such, it is susceptible to variations, depending on the current level of satisfaction with living conditions and expectations of the surveyed regarding his future. Accordingly, the measure of subjective poverty ought to be taken into account as a framework for understanding the measures of absolute and relative poverty. In order to perceive the position and poverty of youth, their satisfaction with the environment they live in, and social exclusion of the young, it is possible to use a questionnaire used to express subjective welfare. Construction of these questions depends on the needs, and they can be in the form of open questions, multiple answers questions, or in theform of scales (Petrović, 2013:19-20). In SILC research,

2

Survey on Income and Living Conditions 
the possibility of a household to "make ends meet" actually represents an indicator of subjective poverty.

Šućur (2006:246) thinks that, when designing questions regarding subjective poverty, in order to get more reliable answers it is more purposeful to formulate the questions which would allow the surveyed to identify himself within the referent groups, instead expecting the surveyed to provide an evaluation of a concrete financial level which marks the poverty limit. The same author (2006:246) explains this by a potential occurrence of abstinence with the surveyed when asked to rate the necessary or desired level of income, which can affect the quality of the answer.

Subjective poverty of youth in rural areas will be covered by a set of questions shown in the section Research results - Perceptions of youth from rural areas about poverty and their position.

\section{Data Regarding Poverty of Youth in Rural Areas of Serbia}

Despite the fact that the situation of the young has been accentuated as extremely disadvantageous for years, little has been done to change this situation (Ilišin, 2005:132; Nikolić, 2004:7). We have witnessed that an increasing number of political actors have been declaratively asserting the necessity to keep the young, both in villages and in the country, because the young represent the foundation upon which future development of the country will be based (Stojanović, 2017:40-61; Vlada Republike Srbije, 2014). The young, ages between 20 and 34, living in other settlements, represent a significant percentage of total population $(7,22 \%)$, of population living in other settlements (17,79\%) and total population of population ages between 20 and $34(36,62 \%)^{3}$.

"Research done by numerous authors, conducted in the last two decades, noted that poverty particularly affects rural areas (Bogićević et al., 2003:28; Ersado, 2006:9; Babović, 2011:194; Jelić and Jovanović, 2011:186; Stojšin, 2015:368 - taken from Jelić and Kolarević, 2016:218)". Same conclusions were reached by the official research of Statistical Office of the Republic of Serbia (Vukmirović and Smith Govoni, 2008:19; Matković, Krstić and Mijatović, 2015:23) and of the Social inclusion and reduction of poverty task force of the Republic of Serbia, published in Siromaštvo u Srbiji (Poverty in Serbia), conducted for the period between 2010 and 2014 (Mijatović, 2013:39; Mijatović, 2014:19). The mentioned research also accentuated the state of higher level of poverty among youth compared to that among their older compatriots (Matković et. al, 2015:25; Mijatović, 2014:11). Contrary to this, data about poverty recorded in Studija o životnom standardu 2002-2007 (Study about life standard 2002-2007), formed using the principle of expenditure revealed that the young, ages between 20 and 34, do not stand out compared to other age groups, and that

3 Account of authors based on data gathered by the Census of Population, Households and Dwellings in the Republic of Serbia for the year 2011. 
they are even less threatened by poverty than the majority (Vukmirović and Smith Govoni, 2008:21).

Even though the problem of insufficient empowerment of youth in villages has been recognized by the public opinion too, the mechanism of monitoring the state and trends of the problem of poverty in this population has not been adequately developed. General problem of evaluation of data published by the official Statistical Office of the Republic of Serbia and the entire coverage of the monitored phenomenon, consists of the inability to disaggregate a string of indicators needed to successfully analyze important segments of social life. The previous passage confirms this.

SILC research, that has been conducted in Serbia since 2013, also doesn't allow for the examination of youth poverty in rural areas. Multiple indicators gathered during SILC research provide an insight in the differences of income and living conditions, either in relation to the level of urbanization (for cities, towns and suburbs and rural areas) or in relation to age groups, comparable to those in EU countries and countries in in process of joining the EU. However, it is impossible to "cross-reference" data using these two criteria. Depending on the year of SILC research, Eurostat publishes data of variables of insufficiently researched aspects of social inclusion. This data, contained in the so-called ad-hoc modules (EU-SILC ad boc modules), does not include dissemination in relation to the level of urbanization. These types of limitations support the fact that, despite an expanded specter of indicators, the mechanism used to monitor poverty in Serbia and the EU does not allow for the identification of those individuals who need help to exit the circle of poverty the most. Namely, none of the existing approaches enables us to identify common characteristics of youth in the circle of poverty, such are: size of the settlement they live in, distance of their settlement from major municipal centers, level of education of youth, gender of the young, etc.

The most extensive research of poverty, i.e. social exclusion in rural areas of Serbia, was conducted by a group of authors in 2010, under the patronage of $U N D P^{4}$. This research did not recognize the young, ages between 15 and 24, as an age group particularly endangered by the problem of poverty and material deprivation. Namely, according to the results of the said research, the young do not deviate negatively from the indications of financial poverty and the indications of material deprivation of other age groups (Cvejić et al., 2010:52). Authors highlight children, ages 0 to 14, as an age group that is especially affected by financial poverty and material deprivation in rural areas (Cvejic et al., 2010:11). In more than a third of youth (38\%), ages between 15 and 24, in rural areas, indications of financial poverty were established, while indications of material deprivation were recorded with $32,8 \%$ of members of this age group (Cvejić et al., 2010:52). This data indicates that research in poverty of youth in rural areas of Serbia is necessary in future. 
In order to analyze the dynamics of youth poverty in rural areas in continuity, it is necessary to include local institutions in the process of problem monitoring. However, local level monitoring of the problem of poverty is also limited by problems of context understanding and problems of covering reference groups. Namely, despite the proposed indicators for social inclusion monitoring ${ }^{5}$, which include indicators of financial poverty and material deprivation, most of them is inapplicable to rural areas population. Indicators of financial poverty in Babović et al. (2012:17) are based on the evaluation of data regarding the number and structure of monetary social assistance and one-time social aid users, found in databases of the Ministry of Labor, Employment, Veteran and Social Policy and Social Work centers. These indicators can be calculated using the Socijalni profil opština (Social profile of municipalities) database, formed by the Ministry of Labor, Employment and Social Policy of the Republic of Serbia ${ }^{6}$. The first problem of data evaluation from this database used for monitoring youth poverty in rural areas occurs due to inadequate division of age groups. Namely, we can say that the mentioned database, regarding the 18 to 26 age group, can be observed as youth group. However, by forming the second (at the same time the largest) age group, ages 27 to 65 , the context of data monitoring and comparison of poverty in different age groups is disturbed. The assumption that the youth population is represented by the 18 to 26 age group creates the second problem. Disaggregation, for the purpose of creation of a dichotomy of urban (more urban) and rural (more rural) settlements, is only possible by disaggregating settlements into those municipalities with cities as their centers, and municipalities with centers which are not cities. Therefore, it is not possible to gather data that will reveal the number of social aid users stationed in urban, i.e. other settlements. If we are unable to gather such data, it implies that we are unable to identify which groups are in need of assistance in their struggle with poverty. Simply put, it is possible that the majority of social aid users in municipalities with a city as their center is actually located in other settlements, or that, for example, the majority of social aid users in municipalities with non-city centers is actually recorded in the municipality's urban settlements. Chart 1 shows the percentage of monetary social aid users (MSA), ages between 18 and 26, according to the type of municipality they live in. Hypothetically, in more urban municipalities (municipalities with cities as their centers), the percentage of MSA users, ages 18 to 26, is lower in both observed groups, compared to the same age group in more rural municipalities (municipalities with non-city centers). This data doesn't say much about youth poverty outside of cities.

5 Babović, M., Vuković, O., Cvejić, S. \& Vuković, D. (2012). Socijalno uključivanje na lokalnom nivou - lista indikatora (Social inclusion on local level - list of indicators). Beograd: SeConS - Grupa za razvojnu inicijativu.

6 http://www.minrzs.gov.rs/lat/socijalni-profil-opstina.html (Accessed on: 13/07/2017) 
Chart 1.

Percentage of MSA users, ages between 18 and 26, according to the type of municipality they reside in

\begin{tabular}{|c|c|c|}
\hline \multirow{2}{*}{ Municipality type } & \multicolumn{2}{|c|}{ Percentage of MSA users, ages between 18 and 26} \\
\hline & January 2011. & January 2014. \\
\hline Municipalities with cities as their centers ${ }^{7}$ & $1,62 \%$ & $2,99 \%$ \\
\hline Municipalities without cities as their centers & $2,67 \%$ & $4,68 \%$ \\
\hline
\end{tabular}

Source: Calculated by authors based on the Socijalni profil opština database, formed by the Republic of Serbia's Ministry of Labor, Employment, Veteran and Social Policy

Socijalni profil opština database stopped being created in 2015, while Social Work centers data about MSA users are not publicly accessible. Given that these are data of public significance, it is possible to obtain them through municipal Social Work centers. However, it is necessary for this data to become publicly accessible, in order to understand the problem of poverty in rural areas of Serbia. On the other hand, indicators of material deprivation (Babović et al., 2012:12) are based upon data gathered by the Statistical Office of the Republic of Serbia for the needs of the Census. The ten-years-long interval for gathering data of such significance indicates an important hiatus in local-level material deprivation monitoring, that must be overcame as soon as possible.

\section{Research Results - Perceptions of Youth from Rural Areas About Poverty and their Position}

\subsection{Defining Poverty by Youth in Rural Areas}

Even though the problem of poverty is a publicly well represented issue, this subject remains largely unknown to a fair share of youth. Namely, one in four surveyed in this research has no vision about poverty $(25,51 \%)$. These survey subjects were unable to remember any notion or situation that is associated with poverty. The young in rural areas perceive the problem of poverty primarily as lack of basic living conditions (25,5\%), along with lack of financial means (23,5\%). Graphic 1 shows coded answers, of the young in rural areas, to the following question: "How would you describe poverty?".

7 Articles 20 and 21, of the Law on Territorial Organization (Official Gazette of RS, No. 29/2007 and 18/2016) defined the following as cities in the Republic of Serbia: Valjevo, Vranje, Zaječar, Zrenjanin, Jagodina, Kragujevac, Kraljevo, Kruševac, Leskovac, Loznica, Niš, Novi Pazar, Novi Sad, Pančevo, Požarevac, Priština, Smederevo, Sombor, Sremska Mitrovica, Subotica, Užice, Čačak, Šabac and Belgrade. 
Graphic 1.

Defining poverty by youth in rural areas, expressed in percentages

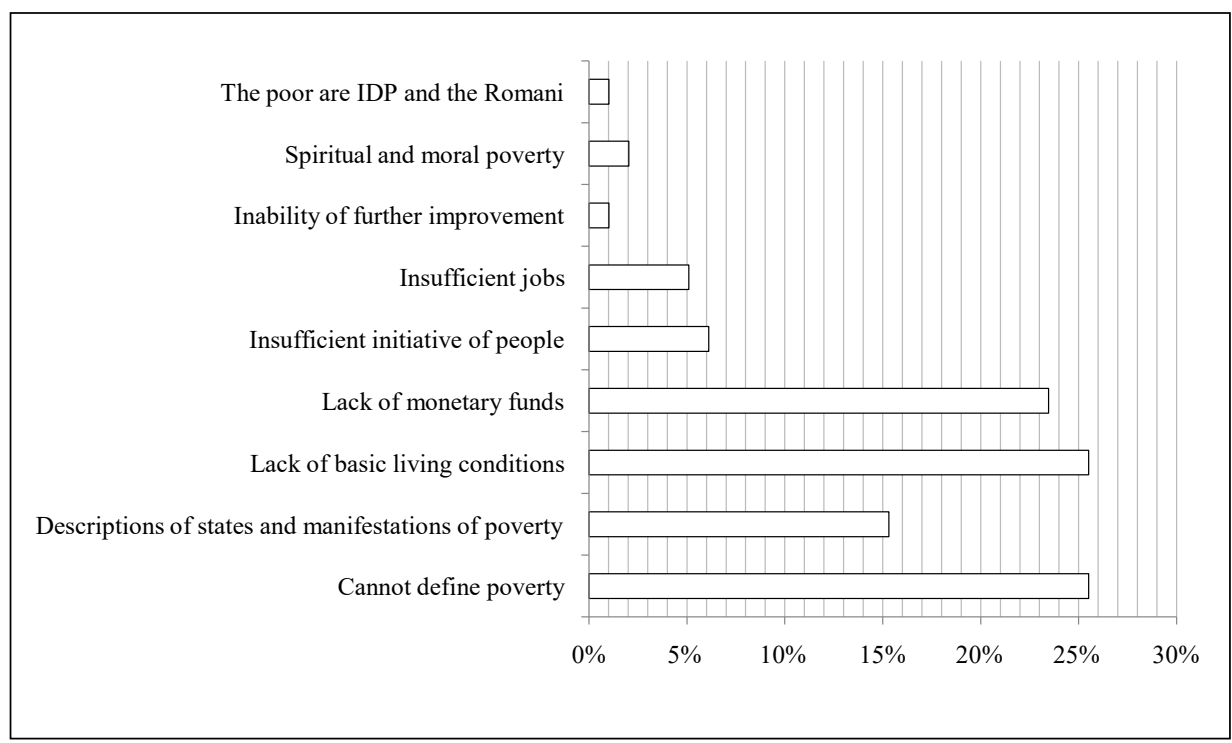

By categorizing systemized answers ${ }^{8}$, we have established that the young from rural areas, who had provided answers to this question, mostly identify poverty with poverty on the very edge of survival (87,2\%). Only $10,3 \%$ of answers referred to identification of poverty as spiritual and emotional poverty. Cultural and educational poverty is not in rural area youth's focus, given the fact that only one survey subject equaled poverty to this category. Also, only one survey subject recognized poverty as poverty of the Romani national minority and poverty of internally displaced persons (IDP) who had to relocate due to war, which is a part of social poverty.

\subsection{Subjective Poverty of Youth in Rural Areas}

In this research, subjective poverty was evaluated by interpreting answers given to the question: "According to your opinion, how far above or below are you from the level of income necessary to keep your household outside poverty?" Results are shown in Chart 2.

8 Categorization of answers was performed according to Stančić and Dimitrijević (2005:27), into the following categories: Poverty on the edge of survival, Poverty in the sphere of culture and education, Social poverty, and Spiritual and Emotional poverty. 
Chart 2.

Subjective poverty of youth in rural areas, according to the distance of their place of residence from the municipality's center and according to age group, expressed through answers to the question: "According to your opinion, how far above or below are you from the level of income necessary to keep your household outside poverty?"

\begin{tabular}{|c|c|c|c|c|c|c|c|}
\hline & & 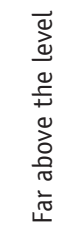 & 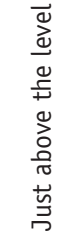 & 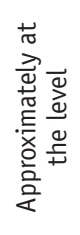 & 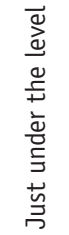 & 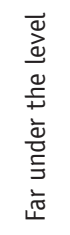 & $\begin{array}{l}\vec{\pi} \\
\stackrel{0}{0}\end{array}$ \\
\hline \multirow{2}{*}{$\begin{array}{l}\text { Distance of } \\
\text { settlement }\end{array}$} & $\begin{array}{l}\text { Significantly distant } \\
\text { settlements }\end{array}$ & $\begin{array}{c}15 \\
37,5 \%\end{array}$ & $\begin{array}{c}13 \\
32,5 \%\end{array}$ & $\begin{array}{c}8 \\
20,0 \%\end{array}$ & $\begin{array}{c}2 \\
5,0 \%\end{array}$ & $\begin{array}{c}2 \\
5,0 \%\end{array}$ & $\begin{array}{c}40 \\
100,0 \%\end{array}$ \\
\hline & $\begin{array}{l}\text { Settlements in the vicinity of } \\
\text { municipality's center }\end{array}$ & $\begin{array}{c}9 \\
25,0 \%\end{array}$ & $\begin{array}{c}14 \\
38,9 \%\end{array}$ & $\begin{array}{c}9 \\
25,0 \%\end{array}$ & $\begin{array}{c}1 \\
2,8 \%\end{array}$ & $\begin{array}{c}3 \\
8,3 \%\end{array}$ & $\begin{array}{c}36 \\
100,0 \%\end{array}$ \\
\hline \multicolumn{2}{|r|}{ Total } & $\begin{array}{c}24 \\
31,6 \%\end{array}$ & $\begin{array}{c}27 \\
35,5 \%\end{array}$ & $\begin{array}{c}17 \\
22,4 \%\end{array}$ & $\begin{array}{c}3 \\
3,9 \%\end{array}$ & $\begin{array}{l}5 \\
6,6 \%\end{array}$ & $\begin{array}{c}76 \\
100,0 \%\end{array}$ \\
\hline \multirow{3}{*}{ Age group } & $20-24$ & $\begin{array}{c}7 \\
35,0 \%\end{array}$ & $\begin{array}{c}10 \\
50,0 \%\end{array}$ & $\begin{array}{c}2 \\
10,0 \%\end{array}$ & $\begin{array}{c}1 \\
5,0 \%\end{array}$ & $\begin{array}{c}0 \\
0,0 \%\end{array}$ & $\begin{array}{c}20 \\
100,0 \%\end{array}$ \\
\hline & $25-29$ & $\begin{array}{c}7 \\
29,2 \%\end{array}$ & $\begin{array}{c}9 \\
37,5 \%\end{array}$ & $\begin{array}{c}6 \\
25,0 \%\end{array}$ & $\begin{array}{c}0 \\
0,0 \%\end{array}$ & $\begin{array}{c}2 \\
8,3 \%\end{array}$ & $\begin{array}{c}24 \\
100,0 \%\end{array}$ \\
\hline & $30-34$ & $\begin{array}{c}10 \\
31,3 \%\end{array}$ & $\begin{array}{c}8 \\
25,0 \%\end{array}$ & $\begin{array}{c}9 \\
28,1 \%\end{array}$ & $\begin{array}{l}2 \\
6,3 \%\end{array}$ & $\begin{array}{c}3 \\
9,4 \%\end{array}$ & $\begin{array}{c}32 \\
100,0 \%\end{array}$ \\
\hline
\end{tabular}

A significant number of survey subjects (22) was unable to rate the income of their household compared to the imagined line of poverty. Only $5 \%$ of surveyed subjects belonging to the youngest age group, 20 to 24, are placed below poverty line, determined by the concept of subjective poverty. Older age groups are in a more disadvantageous position, given the fact that $8,3 \%$ of surveyed subjects, ages 25 to 29 and 15,7\% of subjects from the oldest age group (30 to 34) are below poverty line. On the other hand, by observing the criteria of settlement's distance from the municipality's center, we can reach a conclusion that the young in significantly distant settlements feel less endangered. Of the total number of subjects, $70 \%$ of those living in significantly distant settlements consider themselves to be above poverty line, opposed to $64,5 \%$ of youth living in settlements closer to municipality centers. Total poverty was rated using the answers of $10,5 \%$ of youth from rural areas, who find that their income is insufficient to keep them from poverty. However, the percentage of those subjects who perceive themselves as being on poverty line is no negligible (22.4\%), which proves that a significant percentage of youth in villages is in risk of poverty. The other variable used to evaluate subjective poverty of the surveyed is the attitude of youth towards the representation of the feeling of poverty during their life. 
Chart 3.

Subjective poverty of youth in rural areas, according to the distance of their place of residence from the municipality's center and according to age group, expressed through answers to the question: "How often in your life have you had the feeling of living in poverty, by the standards of the time?"

\begin{tabular}{|c|c|c|c|c|c|c|c|}
\hline & & $\frac{\bar{d}}{\grave{\nu}}$ & $\begin{array}{l}\text { है } \\
\text { 믈 } \\
\text { ज }\end{array}$ & 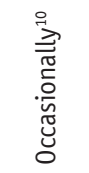 & 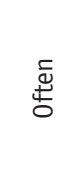 & 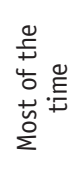 & $\begin{array}{l}\vec{\pi} \\
\stackrel{0}{0}\end{array}$ \\
\hline \multirow{2}{*}{$\begin{array}{l}\text { Distance of } \\
\text { settlement }\end{array}$} & $\begin{array}{l}\text { Significantly distant } \\
\text { settlements }\end{array}$ & $\begin{array}{c}17 \\
32,7 \%\end{array}$ & $\begin{array}{c}13 \\
25,0 \%\end{array}$ & $\begin{array}{c}16 \\
30,8 \%\end{array}$ & $\begin{array}{c}1 \\
1,9 \%\end{array}$ & $\begin{array}{c}5 \\
9,6 \%\end{array}$ & $\begin{array}{c}52 \\
100,0 \%\end{array}$ \\
\hline & $\begin{array}{c}\text { Settlements in the vicinity of } \\
\text { municipality's center }\end{array}$ & $\begin{array}{c}6 \\
13,0 \% \\
\end{array}$ & $\begin{array}{c}15 \\
32,6 \% \\
\end{array}$ & $\begin{array}{c}15 \\
32,6 \% \\
\end{array}$ & $\begin{array}{c}8 \\
17,4 \% \\
\end{array}$ & $\begin{array}{c}2 \\
4,3 \% \\
\end{array}$ & $\begin{array}{c}46 \\
100,0 \% \\
\end{array}$ \\
\hline \multicolumn{2}{|r|}{ Total } & $\begin{array}{c}23 \\
23,5 \% \\
\end{array}$ & $\begin{array}{c}28 \\
28,6 \% \\
\end{array}$ & $\begin{array}{c}31 \\
31,6 \% \\
\end{array}$ & $\begin{array}{c}9 \\
9,2 \% \\
\end{array}$ & $\begin{array}{c}7 \\
7,1 \% \\
\end{array}$ & $\begin{array}{c}98 \\
100,0 \% \\
\end{array}$ \\
\hline \multirow{3}{*}{ Age group } & $20-24$ & $\begin{array}{c}9 \\
31,0 \%\end{array}$ & $\begin{array}{c}10 \\
34,5 \%\end{array}$ & $\begin{array}{c}8 \\
27,6 \%\end{array}$ & $\begin{array}{c}2 \\
6,9 \%\end{array}$ & $\begin{array}{c}0 \\
0,0 \%\end{array}$ & $\begin{array}{c}29 \\
100,0 \%\end{array}$ \\
\hline & $25-29$ & $\begin{array}{c}5 \\
16,7 \% \\
\end{array}$ & $\begin{array}{c}10 \\
33,3 \% \\
\end{array}$ & $\begin{array}{c}9 \\
30,0 \% \\
\end{array}$ & $\begin{array}{c}2 \\
6,7 \% \\
\end{array}$ & $\begin{array}{c}4 \\
13,3 \% \\
\end{array}$ & $\begin{array}{c}30 \\
100,0 \% \\
\end{array}$ \\
\hline & $30-34$ & $\begin{array}{c}9 \\
23,1 \%\end{array}$ & $\begin{array}{c}8 \\
20,5 \%\end{array}$ & $\begin{array}{c}14 \\
35,9 \%\end{array}$ & $\begin{array}{c}5 \\
12,8 \%\end{array}$ & $\begin{array}{c}3 \\
7,7 \%\end{array}$ & $\begin{array}{c}39 \\
100,0 \%\end{array}$ \\
\hline
\end{tabular}

This variable confirms that younger age groups from rural areas are in less risk of poverty. Namely, two thirds of the young, ages 20 to 24, from rural areas consider that they had not faced poverty, to a significant extent, in their life. On the other hand, a larger representation of the feeling of poverty in various periods of life was recorded in older age groups (half of those in the 25 to 29 age group, and 55,4\% of those in the 30 to 34 age group). The young living in significantly distant settlements felt less endangered, compared to their peers living closer to municipality's center. One in five subjects $(21,7 \%)$ living in the vicinity of municipality's center had felt poor, according to standards of the time, often or most of the time in their life, while only one in eight $(11,5 \%)$ subjects from significantly distant settlementsfelt the same. Those individuals who possess a better soil structure are in less peril of poverty (Bogdanov \& Petrović, 2010), which could represent a potential factor for a lower level of subjective poverty in youth in significantly distant rural settlements, along with a stronger focus of households towards agriculture. However, caution is advised when evaluating results about subjective poverty of youth, as they might be a consequence of a paradoxical state. Namely, Bird et al. (2010:11) consider that people may feel less poor in distant areas due to a high level of poverty of other members of their community, or at times due to their small-sized community.

Having in mind the results shown in charts 2 and 3, a small review is needed, in the form of a comparation between the results and subjective poverty of the entire population of the Republic of Serbia. Households that struggle to "make ends meet"

9 occasionally is from time to time; now and then; once in a while; irregularly; at infrequent intervals

10 seldom is infrequently, rarely. 
make $32.7 \%$ of all households (Republički zavod za statistiku, 2017b:3). Based on the results of this research, we have determined that somewhere between $6.6 \%$ and $7.1 \%$ of youth in rural areas find themselves in the same position. These are the young people that rated their position in the most unfavorable manner using via two variables shown in the previous two charts. Gained data indicates that youth in rural areas do not represent a category of population particularly inperiled by poverty.

\subsection{Social Exclusion of Youth in Rural Areas Due to Financial Poverty}

Due to lack of funds and the inability of employment, the young are often excluded from society. Social exclusion of youth in rural areas, due to lack of money, reveals the extent to which monetary deprivation affects lives of village youth. One in two subjects, ages 30 to 34 , has felt isolated from his community due to lack of money in the last two years. Younger survey subjects feel less excluded, based on the same criteria, but the recorded percentages are nevertheless high (for the young, ages 20 to 24 , the percentage is $31 \%$, while for those ages 25 to 29 , it is $43,3 \%$ ). Evident gradation in the level of social exclusion is also noticeable via the place of living criterion. Youth in significantly distant rural settlements feel less excluded due to lack of money in comparison to their compatriots who live close to urban centers $(30,8 \%$ in isolated settlements, as opposed to $56,6 \%$ in settlements closer to an urban settlement). Behavior, i.e. leisure activities of youth, differ due to the level of urbanization of their settlements. Stanojević (2012:157-158) established a direct connection between the decrease of urbanization and the rise of significance of socially active leisure activities, in forms of socializing and sports. This way, the young who lack other forms of leisure, create social connections that remain strong, due to a restricted geographical space, tradition, and kinship. In this case, physical distance from an urban settlement may serve as a stimulus for the creation of a stronger bond between youth, and a better mutual understanding of financial scarcity, something that could represent a subject of a new research dealing with the problems of youth in the contryside.

Chart 4.

Social exclusion of youth in rural areas due to financial poverty according to the distance of their place of residence from the municipality's center and according to age group, expressed through answers to the question: "Had there been moments in the past two years, that you had felt isolated from the community you live in, due to lack of money?"

\begin{tabular}{|c|c|c|c|c|}
\hline & & Yes & No & Total \\
\hline \multirow{2}{*}{ Distance of settlement } & Significantly distant settlements & $\begin{array}{c}16 \\
30,8 \%\end{array}$ & $\begin{array}{c}36 \\
69,2 \%\end{array}$ & $\begin{array}{c}52 \\
100,0 \%\end{array}$ \\
\hline & $\begin{array}{c}\text { Settlements in the vicinity of } \\
\text { municipality's center }\end{array}$ & $\begin{array}{c}26 \\
56,5 \% \\
\end{array}$ & $\begin{array}{c}20 \\
43,5 \% \\
\end{array}$ & $\begin{array}{c}46 \\
100,0 \% \\
\end{array}$ \\
\hline \multicolumn{2}{|r|}{ Total } & $\begin{array}{c}42 \\
42,9 \%\end{array}$ & $\begin{array}{c}56 \\
57,1 \%\end{array}$ & $\begin{array}{c}98 \\
100,0 \%\end{array}$ \\
\hline \multirow{3}{*}{ Age group } & $20-24$ & $\begin{array}{c}9 \\
31,0 \% \\
\end{array}$ & $\begin{array}{c}20 \\
69,0 \%\end{array}$ & $\begin{array}{c}29 \\
100,0 \%\end{array}$ \\
\hline & $25-29$ & $\begin{array}{c}13 \\
43,3 \% \\
\end{array}$ & $\begin{array}{c}17 \\
56,7 \% \\
\end{array}$ & $\begin{array}{c}30 \\
100,0 \% \\
\end{array}$ \\
\hline & $30-34$ & $\begin{array}{c}20 \\
51,3 \%\end{array}$ & $\begin{array}{c}19 \\
48,7 \%\end{array}$ & $\begin{array}{c}39 \\
100,0 \%\end{array}$ \\
\hline
\end{tabular}




\subsection{Actors Who Can Help Young People from Rural Areas in Their Struggle Against Poverty}

Graphic 2 shows attitudes of the young from rural areas, which can be used to conclude from whom do the young expect support in their struggle for improving life standard. Just about every other survey subject was unable to name an institution or an individual who could actively affect the improvement of financial situation of youth in rural areas. This result supports the claim that institutions, and their activities, are insufficiently present in rural areas, and that the young are unaware of their programs for improvement of youth position. Most of the young (about 34\%) think that the state and local governments are pivotal for reduction of youth poverty. Only $8 \%$ of the surveyed think that the problem of youth poverty can be solved via active involvement of business entities and creation of new jobs. The young from rural areas insufficiently rely on their own knowledges and skills, and at the same time on the functional relations generated by institutions such are Youth Offices, Youth Cooperatives, and educational institutions. According to research results, the young consider their role to be small (almost non-existent), in the struggle against poverty, meaning that the young in rural areas are discouraged to a large extent, when it comes to their potentials.

\section{Graphic 2.}

Answers of youth in rural areas to the question: "Which institutions, organizations, or individuals could be of use to youth in their struggle against poverty?", expressed in percentages

\begin{tabular}{|r|r|r|}
\hline The young as individuals \\
Business entities \\
Red Cross
\end{tabular}

\section{Conclusion}

The young in rural areas represent a significant portion of population in Serbia. However, some of them are facing poverty. We have established that the problem of youth poverty in rural areas is not sufficiently covered by research in the Republic of Serbia. This paper presents data regarding subjective poverty of youth in rural areas, data that can be used to recognize the proportions of this problem for the mentioned population. 
Due to high incidence of financial poverty and material deprivation of youth in rural areas of Serbia, recorded in research done so far, show that it is necessary to monitor these phenomena and to determine their causes. Opinions about the problem of youth poverty in rural areas of Serbia differ. Even though numerous attitudes of authors indicate that the young are not in a position that is any more disadvantageous than the position of other age categories, this category definitely deserves more significant monitoring through scientific research.

Surveyed subjects predominantly observe the problem of poverty as lack of basic living means, and lack of financial means. Surveyed individuals rarely identified this problem as spiritual and emotional poverty, as well as poverty of culture and education. Inability of $25,5 \%$ of surveyed subjects to describe the problem of poverty indicates that the young are insufficiently familiar with this problem.

Data regarding subjective poverty indicates that one in ten surveyed subjects is poor. The subjects belonging to the oldest age group (30-34 years of age), and residents of settlements in the vicinity of municipality centers are in a more disadvantageous position. The other variable confirms that these categories are in a more disadvantageous position when it comes to poverty. Also, this variable was used to determine that the young in rural areas had greatly faced the problem of their own poverty in their lifetime.

Financial poverty of youth in rural areas of Serbia significantly causes their social exclusion. This phenomenon was recorded in $42 \%$ of subjects, who claimed that they had felt isolated from their community at some point in the last two years, due to lack of money.

Previously presented data support the claim that the problem of the lack of data regarding the problem of poverty can be compensated by examining subjective poverty. This method of examination is not just a necessity, but also a need for the purpose of discovering common characteristics of those individuals who are "trapped" by poverty. By determining these specificities, we can greatly facilitate the understanding of a complex concept, such is poverty.

\section{References}

1. Babović, M. (2011). Socijalno uključivanje: koncepti, stanje, politike. Beograd: SeCons -Grupa za razvojnu inicijativu.

2. Babović, M.; Vuković, O.; Cvejić, S.; Vuković, D. (2012). Socijalno uključivanje na lokalnom nivou - lista indikatora. Beograd: SeConS - Grupa za razvojnu inicijativu.

3. Bird, K.; McKay, A. and Shinyekwa, I. (2011). Isolation and poverty: The relationship between spatially differentiated acces to goods and services and poverty. London: Chronic Poverty Research Center.

4. Bogdanov, N. and Petrovic, M. (2010). Financial Poverty and Material Deprivation in Rural Serbia. Brussels: Conference Western Balkans: Poverty and Inclusion. 
5. Bogićević, B.; Krstić, G.; Mijatović, B.; Milanović, B. (2003). Siromaštvo i reforma finansijske podrške siromašnima. Beograd: Centar za liberalno-demokratske studije.

6. Cartmel, F. and Furlong, A. (2000). Youth unemployment in rural areas. York: Joseph Rowntree Foundation.

7. Cvejić, S.; Babović, M.; Petrović, M.; Bogdanov, N.; Olivera, B. (2010). Socijalna isključenost u ruralnim oblastima Srbije. Beograd: UNDP Srbija, Centar za inkluzivni razvoj.

8. Ersado, L. (2006). Rural Vulnerability in Serbia. Washington, DC: World Bank, Europe and Central Asia Region The World Bank

9. Ilišin, V. (2005). Političke vrijednosti, stavovi i participacija mladih: kontinuitet i promjene, u: Ilišin, V. (Ur.). Mladi Hrvatske i europska integracija. Zagreb: Institut za društvena istraživanja u Zagrebu.

10. Jelić, S. i Jovanović, T. (2011). Ruralno stanovništvo i siromaštvo u Srbiji. Ekonomika poljoprivrede, LVIII (Specijalni broj - 2): 175-189.

11. Jelić, S. i Kolarević, V. (2016). Fenomen socijalne isključenosti u periodu tranzicije u Srbiji. Sociološki pregled, vol. L (2016), no. 2: 209-228.

12. Matković, G.; Krstić, G. i Mijatović, B. (2015). Srbija: pribodi i uslovi života 2013. Beograd: Republički zavod za statistiku.

13. Matković, G. (2014). Merenje siromaštva-teorijski koncepti, stanje ipreporuke za Republiku Srbiju. Beograd: Tim za socijalno uključivanje i smanjenje siromaštva.

14. Mijatović, B. (2013). Siromaštvo u Srbiji 2011, 2012. i 2013. godine. Beograd: Tim za socijalno uključivanje i smanjenje siromaštva Vlada Republike Srbije.

15. Mijatović, B. (2015). Siromaštvo u Srbiji u 2014. godini. Beograd: Tim za socijalno uključivanje i smanjenje siromaštva Vlada Republike Srbije.

16. Mojić, D.(2012). Između sela i grada, Mladi u Srbiji u prvoj deceniji trećeg milenijuma. Čigoja štampa, Institut za sociološka istraživanja Filozofskog fakulteta u Beogradu.

17. Nikolić, M. (2004). Uvod: mladi su budućnost ovog društva, u: Nikolić, M. et al. (Ur.). Mladi zagubljeni u tranziciji. Beograd: Centar za proučavanje alternativa.

18. Pavis, S.; Platt, S. and Hubbard, G. (2000). Young people in rural ScotlandPathways to social inclusion and exclusion. York: Joseph Rowntree Foundation.

19. Penttilä, I. and Nordberg, L. (1999). Objective and Subjective Measures of Poverty in the European Community Household Panel. Bulletin of the International Statistical Institute, 52nd Session. https://www.stat.fi/isi99/proceedings/arkisto/ varasto/nord0702.pdf. (Accessed 4 April 2017)

20. Petrović, M. (2013). Subjective Well-Being, Activation Policies, and the Inclusion Agenda in Ruggeri Laderchi C. E Savastano S. Poverty and Exclusion in the Western Balkans. New York: Springer.

21. Republički zavod za statistiku (2015). Siromaštvo $i$ socijalna nejednakost u Republici Srbiji u 2014. RZS, Announcement no. 083. year LXV, Beograd.

22. Republički zavod za statistiku (2017). Anketa o potrošnji domaćinstava: Pribodi u novcu i naturi i lična potrošnja domaćinstava u Republici Srbiji u 2016. RZS, Announcement no. 079 - year LXVII, Beograd.

23. Republički zavod za statistiku (2017). Anketa o pribodima i uslovima života u Republici Srbiji za 2016. godinu. Announcement no. 087, year LXVII, Beograd. 
24. Stančić, S. i Dimitrijević, S. (2005). Mladi o siromaštvu i načinima za njegovo prevazilaženje u Republici Srpskoj. Banja Luka: ART Print.

25. Stanojević, D. (2012). Slobodno vreme mladih, u: Čigoja, Ž. i Mojić, D. (Ur.). Mladi - naša sadašnjost. Istraživanje socijalnih biografija mladih u Srbiji. Beograd: Institut za sociološka istraživanja Filozofskog fakulteta u Beogradu.

26. Stojanović, B. (2017). Alternativni izveštaj o položaju i potrebama mladih u Republici Srbiji. Beograd: Krovna organizacija mladih Srbije.

27. Stojšin, S. (2014). Osnovne dimenzije pojmova socijalne isključenosti i siromaštva - problem indikatora, u: Šljukić, S. i Ristić, D. (Ur.). Strukturne promene u savremenim društvima. Novi Sad: Filozofski fakultet, Odsek za sociologiju.

28. Šućur, Z. (2006). Objektivno i subjektvino siromaštvo u Hrvatskoj. Revija za socijalnu politiku, 13 (3-4): 237-255.

29. Tomanović, S. (2012a). Od omladine do socijalnih biografija mladih u postsocijalističkoj transformaciji društva, u: Čigoja, Ž. i Mojić, D. (Ur.). Mladi - naša sadašnjost. Istraživanje socijalnih biografija mladih u Srbiji. Beograd: Institut za sociološka istraživanja Filozofskog fakulteta u Beogradu.

30. Tomanović, S. (2012b). Tranzicija (prelazak) u odraslost: tempo obeležja i promene in: Čigoja, Ž. i Mojić, D. (Ur.). Mladi - naša sadašnjost. Istraživanje socijalnih biografija mladih u Srbiji. Beograd: Institut za sociološka istraživanja Filozofskog fakulteta u Beogradu.

31. Vlada Republike Srbije (2014). Nacionalna strategija za mlade za period od 2015. do 2025. godine. Beograd: Službeni glasnik Republike Srbije broj 22/2015.

32. Vukmirović, D. i Smith Govoni, R. (2008). Studija o životnom standardu 20022007. Beograd: Republički zavod za statistiku.

33. Vukmirović, D. (2012a). Popis stanovništva, domaćinstava i stanova u Republici Srbiji 2011: Starost i pol. Beograd: Republički zavod za statistiku.

34. Vukmirović, D. (2012b). Popis stanovništva, domaćinstava i stanova u Republici Srbiji 2011: Sistematski spisak naselja u Republici Srbiji. Beograd: Republički zavod za statistiku.

35. Zakon o teritorijalnoj organizaciji. Službeni glasnik Republike Srbije broj 129/2007 i 18/2016. 
Prethodno priopćenje

Sreten M. Jelić

Sveučilište u Beogradu, Poljoprivredni fakultet, Srbija

e-mail:sjelic@agrif.bg.ac.rs

Vukašin Kolarević

Sveučilište u Beogradu, Poljoprivredni fakultet, Srbija

e-mail: vukasinkolarevic@gmail.com

\section{Subjektivni doživljaj siromaštva među mladima u ruralnim područjima Srbije}

\section{Sažetak}

Neimaština je kompleksan fenomen s kojim se suočavaju mladi ljudi u današnje vrijeme. Namjera je ovoga članka utvrditi prisutnost tog problema među mladim stanovništvom ruralnih područja Srbije. Istraživanje je provedeno u pet sela općine Paraćin na uzorku od 98 mladih žena i muškaraca u dobi od 20 do 34 godine. Postavljena su im pitanja o siromaštvu i zatraženo je da procijene vlastitu neimaštinu i posljedičnu društvenu isključenost. Istraživanje je provedeno empirijskom metodom u ranije spomenutim područjima. Rezultati rada na terenu predstavljeni su u drugom dijelu članka. Za bolju procjenu položaja i siromaštva mladih, njihovog zadovoljstva životnom okolinom te percepciju socijalne isključenosti korišten je upitnik koji omogućuje subjektivan iskaz o osobnom blagostanju. Podaci dobiveni istraživanjem pokazuju da je jedan od deset ispitanika siromašan. U lošijem su položaju ispitanici iz najstarije dobne skupine (30 - 34 godine) kao i stanovnici koji žive u blizini središnjeg gradskog naselja. Rezultati pokazuju da se mladi iz ruralnih područja susreću s problemom siromaštva u velikoj mjeri cijeli svoj život. Društvena isključenost zabilježena je kod $42 \%$ sudionika koji tvrde da su se u protekle dvije godine osjećali izolirani od zajednice zbog nedostatka novca.

Ključne riječi: subjektivno siromaštvo, mladi ljudi, ruralna područja, društvena isključenost. 